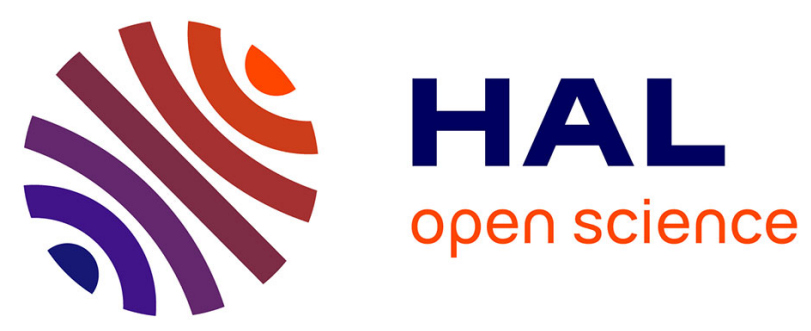

\title{
INFLUENCE OF THE SPREAD IN VALUES OF ALUMINIUM ALLOY DYNAMIC PROPERTIES UPON THE FINAL RESULTS OF MAGNETIC-PULSE STRAIN
}

V. Glouschenkov, R. Novobratsky, A. Bourmistrov

\section{To cite this version:}

V. Glouschenkov, R. Novobratsky, A. Bourmistrov. INFLUENCE OF THE SPREAD IN VALUES OF ALUMINIUM ALLOY DYNAMIC PROPERTIES UPON THE FINAL RESULTS OF MAGNETIC-PULSE STRAIN. Journal de Physique IV Proceedings, 1991, 01 (C3), pp.C3-331-C3334. 10.1051/jp4:1991347. jpa-00250491

\section{HAL Id: jpa-00250491 https://hal.science/jpa-00250491}

Submitted on 1 Jan 1991

HAL is a multi-disciplinary open access archive for the deposit and dissemination of scientific research documents, whether they are published or not. The documents may come from teaching and research institutions in France or abroad, or from public or private research centers.
L'archive ouverte pluridisciplinaire HAL, est destinée au dépôt et à la diffusion de documents scientifiques de niveau recherche, publiés ou non, émanant des établissements d'enseignement et de recherche français ou étrangers, des laboratoires publics ou privés. 
Colloque C3, suppl. au Journal de Physique III, Vol. 1, octobre 1991

\title{
INFLUENCE OF THE SPREAD IN VALUES OF ALUMINIUM ALLOY DYNAMIC PROPERTIES UPON THE FINAL RESULTS OF MAGNETIC-PULSE STRAIN
}

\author{
V. GLOUSCHENKOV, R. NOVOBRATSKY and A. BOURMISTROV \\ 34. Moskovskoye Shosse, Kuibyshev Aviation Institute, Samara, \\ 443086, USSR
}

\begin{abstract}
Résumé: Dans cette étude on fournit un modèle mathématique pour un procédé d'expansion de tubes par impulsion magnétique au moyen d'une approximation par la loi puissance de la courbe d'écrouissage dynamique $\sigma_{\mathrm{i}}=\mathrm{k} \varepsilon_{\mathrm{i}}^{\mathrm{n}}$. La méthode par éléments finis permet d'analyser les déformations dues aux contraintes du matériau tubulaire dans le procédé d'expansion par impulsion magnétiquc et d'estimer l'influence de la dispersion des facteurs $k$ et $n$ sur les résultats de la déformation finale. Les limites de la dispersion des factcurs $k$ et $n$ ont été définis tous deux en fonction des résultats de tests dynamiques cités par d'autres chercheurs sur les alliages d'aluminium et les résultats obtenus par les auteurs.
\end{abstract}

Abstract - The paper provides for mathematical model of magnetic-pulse process for tubular blanks expansion by means of power approximation of the dynamic hardening curve $\sigma_{1}=k \varepsilon_{i}^{n}$. Finite element method allows to analyse stressed strain of the blank material in the process of magnetic-pulse expansion and to estimate the influence of the spread in " $k$ " and " $n$ " factors on final strain results. Boundaries of the spread in " $k$ " and " $n$ " factors were defined both by the results of dynamic teats on aluminium alloys cited by other investigators and by the results obtained by the euthors.

Employment of magnetic-pulse treatment of metels is one of the promising tendencies in the development of present-dey machine buildins. The adopted technique of working out and investigating processes of magnetic-pulse treatment is besed upon the variational principles of mechenics, the plastic flow theory and the adaptation of the finite element method/I/. The computational algorithm is implemented through a package of applied programes for the ES type computers.

However our experience of the package service showed that some processes indicate a considerable divergence of calculated and 
experimental results. Thus, performing a task of an adapter type blank shaping the discrepenoy between calculated displacement values and data obtalned from high-speed filming may reach $30 \%$. One of this divergence possible causes may appear to be errors in specifying the strain metal mechanical properties. Analysis of scientific literature and processing of our own experimental results showed that the spread in values of mechanical properties is rather significant (Table I). Thus, for AMg6M aluminium alloy the spread in " $k$ " factor reaches $40 \%$, the spread in " $n$ " factor is $30 \%$.

Table I

Dynamic values of mechanical properties and hardening constants for some aluminium alloys

\begin{tabular}{|c|c|c|c|c|c|}
\hline \multirow{2}{*}{$\begin{array}{l}\text { Alloy } \\
\text { grades }\end{array}$} & \multicolumn{3}{|c|}{ Mechanical properties } & \multicolumn{2}{|c|}{ Hardening constants } \\
\hline & $\sigma_{b}, \mathrm{MPa}$ & $\sigma_{0,2}, M P a$ & $\delta, \%$ & $\mathrm{k}, \mathrm{MPa}$ & $n$ \\
\hline$A D I$ & II7 & $384-450$ & $27.0-36.0$ & $I 77-I 98$ & $0.268-0.224$ \\
\hline $\mathrm{DI} 6 \mathrm{M}$ & $210-230$ & $I 00-I 45$ & $16.8-22.8$ & $332-357$ & $0.167-0.157$ \\
\hline AMg 3MI & 270 & I68 & $27.0-36.0$ & $\begin{array}{l}40 I .2- \\
44 I .3\end{array}$ & $0 . I 77-0 . I I 8$ \\
\hline$A M g 6 M$ & $390-520$ & $252-286$ & $23.0-32.4$ & $624-892$ & $0.234-0 . I 76$ \\
\hline
\end{tabular}

Influence of the spread in "k" and " $n$ " factors upon the final results was estimated when performing a test task of free tubular blank expansion having the length of $30 \mathrm{~mm}$, the outer diameter of $60 \mathrm{~mm}$ and the thickness of $1.0 \mathrm{~mm}$ and being made of AMg $3 M$ aluminium alloy. To run a check a blank expansion was conducted under the capacitor bank charge $W=I .83 \mathrm{~kJ}$ by means of a magnetic-pulge installation with the following parameters: capacitor bank capacitance $\mathrm{C}=77.9 \cdot 10^{-6} \mathrm{~F}$; inductance $\mathrm{L}=0.254 \cdot \mathrm{IO}^{-6} \mathrm{H}$; resistance $R=0.0 I 32 \Omega$.

Load inductance was equal to $5.6 \cdot \mathrm{IO}^{-7} \mathrm{H}$. The task was performed with the help of the numerical method for two-dimensionel problems. The amount of finite elements through the blank thickness counted as 4 (Fig.I). The calculation results with $k=k_{\text {mean }}$ and $n=n_{\text {mean }}$ were recognized as besic ones. 


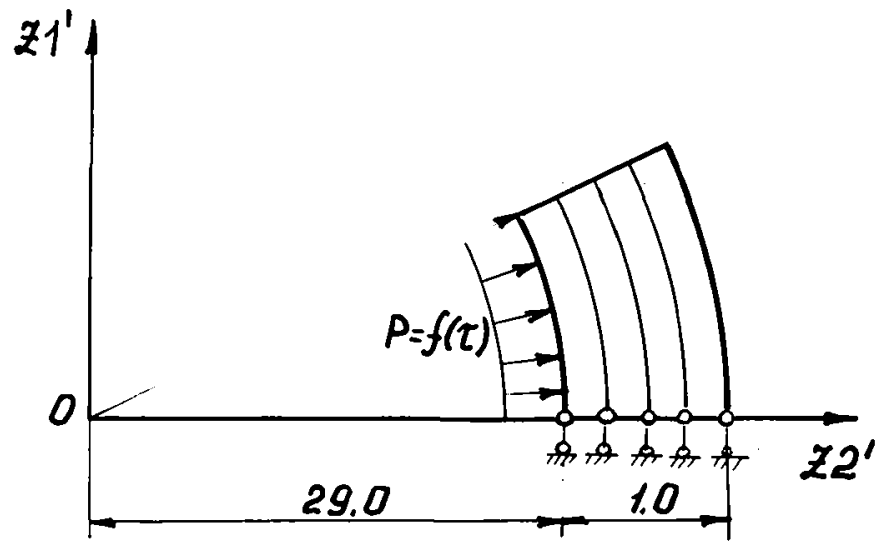

Fig.I. The calculated scheme of a iree tubular blank expansion

Figure 2 shows an example of two plots of a blank outer surface atsplacement in time.

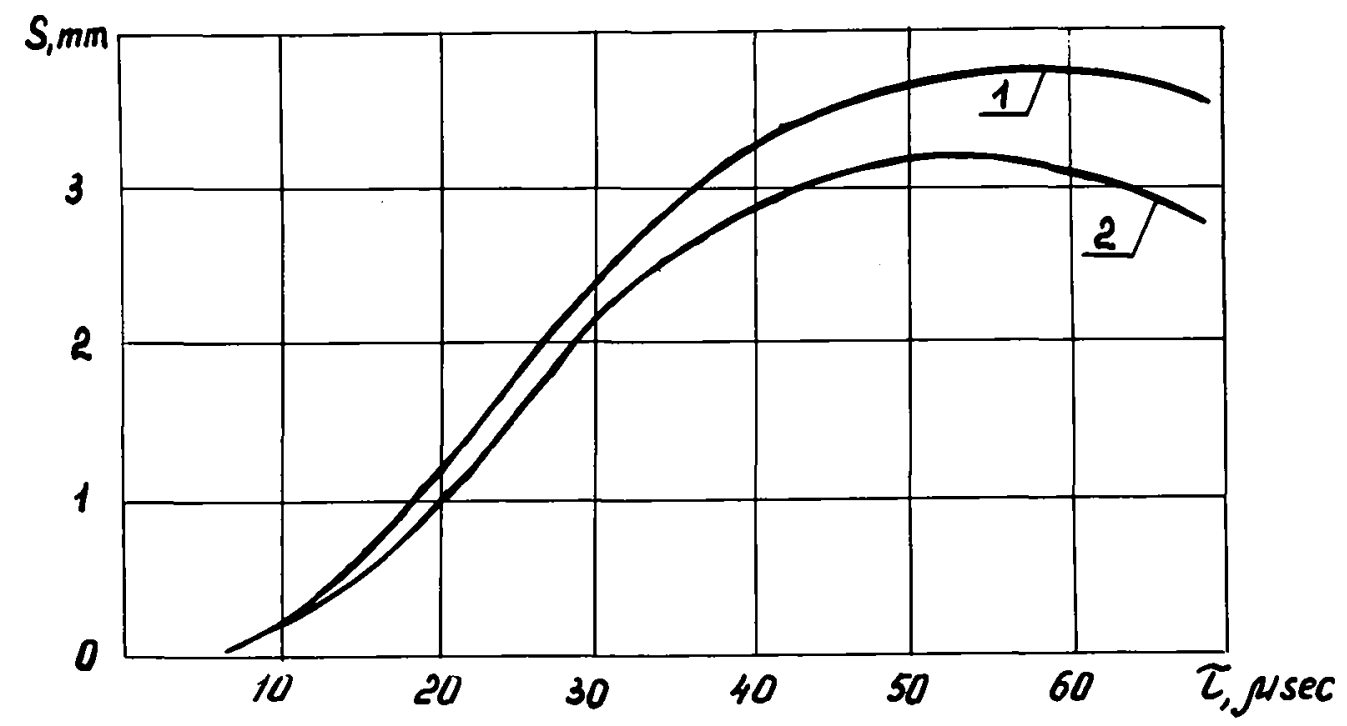

Fig.2. Displacement of the blank outer surface:

I) $k=k_{\text {mean }}, n=n_{\text {mean }}$; 2) $k=k_{\max }, n=n_{m i n}$ 
Analysis of the plots allows to come to the following conclusion: during the inftial stage of a tubular blank expansion process the divergence of $S=S($ ) curves is insignificant, with the increase of strain degree the divergence value is growing. In this connection it is extremely significent to consider displacement values with various combinations of " $k$ " and " $n$ " factors at typical time intervals $\tau$ (Table 2).

Table 2

Displacement of the blank outer surface at typical time intervals

\begin{tabular}{clllll}
\hline $\begin{array}{l}\text { Hardening } \\
\text { constants }\end{array}$ & \multicolumn{2}{c}{$\begin{array}{c}\text { Displacement, } \\
\mathrm{mm}\end{array}$} & & \multicolumn{2}{c}{$\begin{array}{l}\text { Deviation of displacement } \\
\text { values from basic mag- } \\
\text { nitudes, } \%\end{array}$} \\
\hline $\mathrm{k}$ & $\mathrm{n}$ & $\tau=30 \mu \mathrm{sec}$ & $\tau=60 \mu \mathrm{sec}$ & $\tau=30 \mu \mathrm{sec}$ & $\tau=60 \mu \mathrm{sec}$ \\
\hline$k_{\operatorname{mean}}$ & $n_{\operatorname{mean}}$ & 2.28 & $3.6 I$ & 0 & 0 \\
$k_{\operatorname{mean}}$ & $n_{\max }$ & 2.36 & 4.08 & 3.74 & $I 3.02$ \\
$k_{\operatorname{mean}}$ & $n_{\min }$ & $2 . I 7$ & 3.06 & -4.62 & $-I 5.24$ \\
$k_{\max }$ & $n_{\operatorname{mean}}$ & 2.24 & 3.36 & $-I .76$ & -6.93 \\
$k_{\max }$ & $n_{\min }$ & $2 . I 7$ & $2.9 I$ & -4.84 & $-I 9.40$ \\
$k_{\min }$ & $n_{\max }$ & 2.39 & $4.3 I$ & 4.84 & $I 9.40$ \\
$k_{\min }$ & $n_{\operatorname{mean}}$ & $2.3 I$ & 3.87 & $I .54$ & 7.20 \\
\hline
\end{tabular}

The data given in Table 2 allow to estimate the calculation error due to the spread in hardening dynamic constant values of the blank materlal. With high degrees of strain (operations of blank shaping) the calculation error may reach $20 \%$, with low degrees of strain (operations of calibration) it does not exceed $5 \%$.

Reference

I. Сахаров A.C. Моментная схема конечных өлементов (МСКә) с учетом жестиих смедений // Сопротивление материалов и теория соорухении. -Киев. :Будивельнин, I974, вып .XXIУ.C. $147-156$ 